\title{
Relevance of Corporate Social Responsibility to Companies During Turbulent Economic Times: A Survey of Zimbabwe Stock Exchange Listed Companies
}

\author{
Imelda Sekai Shoko ${ }^{1}$, Vusumuzi Sibanda ${ }^{2} \&$ Ruramayi Tadu ${ }^{2}$ \\ ${ }^{1}$ Graduate School of Business. National University of Science \& Technology, P.O. Box AC 939 Ascot Bulawayo \\ ${ }^{2}$ BA ISAGO University P. Bag BR 94, Gaborone, Botswana \\ Correspondence: Vusumuzi Sibanda, BA ISAGO University P Bag BR 94, Gaborone, Botswana.
}

Received: July 6, 2020

Accepted: July 17, 2020

Online Published: April 20, 2021

doi:10.11114/bms.v7i2.4924

URL: https://doi.org/10.11114/bms.v7i2.4924

\begin{abstract}
Corporate Social Responsibility (CSR) has remained topical and contentious as various schools of thought are put forward on its relationship to cost versus profitability for businesses. This study explored the relevance of CSR and its effect on the survival of businesses during an economic meltdown in Zimbabwe. The study purposively sampled 31 companies that are listed on the Zimbabwe Stock Exchange and have sound CSR programmes. A total of 93 questionnaires were administered and a Chi-square was conducted to test and establish the relationship between CSR strategies and business survival. The study concluded that companies with CSR strategies had a higher chance of surviving during turbulent times. Following the findings of the study, it is recommended that government comes up with CSR policies for different industries and that organisations continue investing in CSR especially in times of economic challenges.
\end{abstract}

Keywords: Zimbabwe Stock Exchange, corporate social responsibility, turbulent times

\section{Introduction and Background}

The concept of CSR is becoming more relevant to public policy makers, trade unions and other actors, who regulate, monitor or influence business behaviors and performance. According to Hopkins, Roche and Hopkins (2008), if anything, CSR is now needed more than ever before. The concept of CSR has been practised by several companies for a long time and has become a global phenomenon though it is debatable on how it should be defined, how effective it is especially during turbulent times and implementation remains a progressively significant and complex area of investigation amongst academia, businesses and society (Horng et al., 2018).

Zimbabwean companies are on an aggressive repositioning drive adopting best practice methods and adherence to international standards in order to survive and remain competitive. According to Baker and Anderson (2010) and Defoe (2020), arguments against CSR are many and their assertion that companies are too busy surviving hard times to focus on issues around CSR aptly captures the Zimbabwean situation. Most companies operating in Zimbabwe tend to focus only on core business with the aim of boosting the bottom line. According to the Confederation of Zimbabwe Industries (CZI) (2011), as Zimbabwe continues to recover from the decade long economic downturn, it is more important than ever, that companies look to improve on performance and investigate new strategies and new markets in order to survive and remain competitive. The CZI clearly indicates that social responsibility is still considered a peripheral concern in companies listed on the Zimbabwean Stock Exchange (ZSE). Stakeholders such as government, shareholders, trade unions, the media, consumer groups and civil society organisations want assurances that business entities are responsible corporate citizens, having regard for society's laws and protecting society's welfare. Further assurance is required that business is taking an active role in finding solutions to the numerous societal problems, many of which result from the operations of such businesses (Onyebuche \& Nwaeke, 2019). In depressed economies such as Zimbabwe, CSR activities are bound to be compromised and treated as peripheral.

The challenge for today's leaders and organisations is to perform effectively in an environment of uncertainty, turbulent economic times and ambiguity, while reconciling the CSR diversity of interests, needs, and demands of multiple stakeholders (Schraa-Liu \& Trompenaars, 2006). The Confederation of Zimbabwe Industries (CZI) 2011 Report states 
that in times of economic downturn in Zimbabwe, there exists a serious misalignment between business survival and corporate social responsibility strategies. Well thought out CSR programmes that align to an organisation's overall strategy are lacking during such times. It has increasingly become difficult for companies to justify charitable expenditures in terms of CSR's contribution to the bottom line within organisations. CSR is relegated to the periphery of business and not considered as a strategic decision-making process that contributes significantly to the bottom line. As such, companies find themselves under extreme pressure to have CSR initiatives that deliver a strong financial result especially during turbulent times. The above outline of the problem triggered an interest to conduct this study whose main objective was: To explore the relevance of CSR to companies during turbulent economic times in Zimbabwe. To address this objective, the following hypothesis was developed:

$\mathrm{H}_{0}$ : There is no relationship between CSR strategies and business survival

$\mathrm{H}_{1}$ : There is a relationship between CSR strategies and business survival

\section{Conceptual Theoretical Framework}

Decades of debate on CSR have resulted in a substantial body of literature offering a number of philosophies which all point to the fact that businesses have an obligation to work for social betterment despite hardships that may emanate especially from the economic front. This research was guided by "The People, Planet and Profit" model. This model was coined by Elkington in 1994. The underlying CSR principle of the triple 'P' model is to provide an overview of the driving forces in finding a proper balance and creating value addition for People, the Planet, and Profits of a company irrespective of whether a business is making profits or not. This conceptual model of balancing People, Planet and Profit is often represented visually as a triangle within which, added value is created. People stands for social wellbeing, Planet for ecological quality and Profit for economic prosperity. The triangle shape symbolises the idea that one ' $\mathrm{P}$ ' should not profit at the expense of another (Jonker, 2006) as shown in Figure 1.

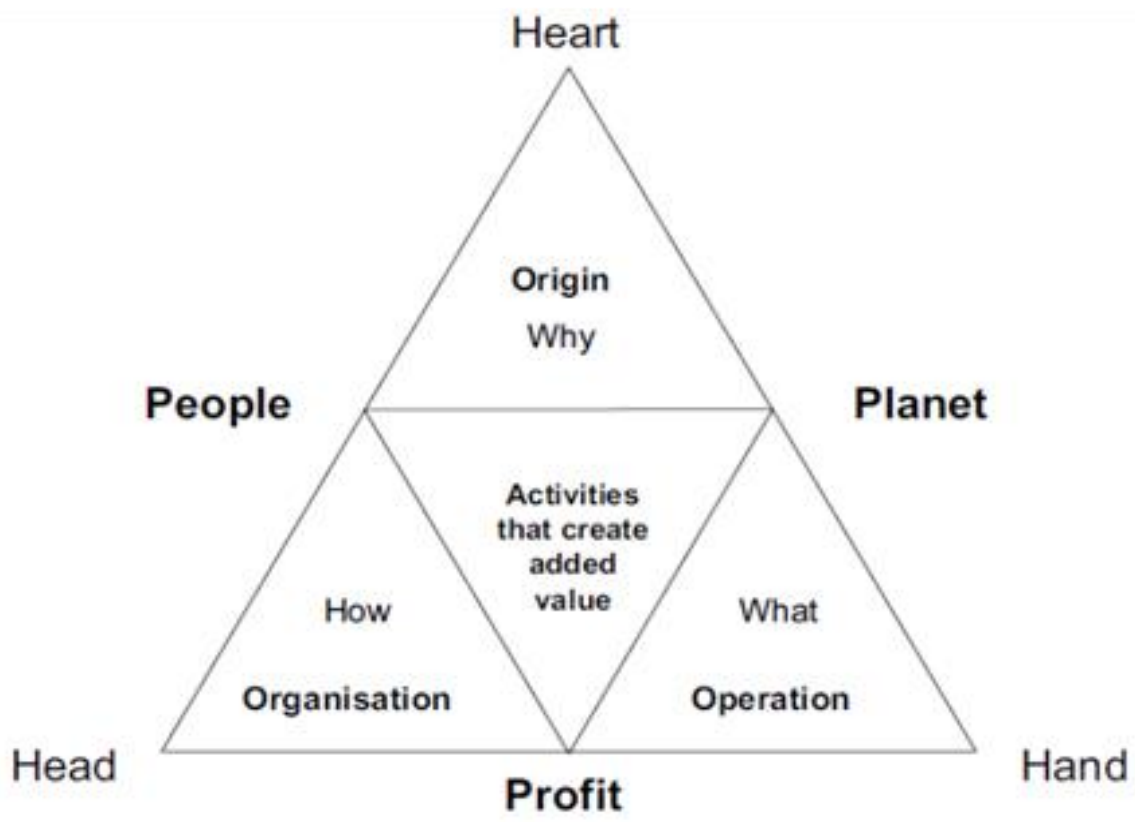

Figure 1. The Conceptual Framework

Source: Bergman et al. (2017)

At any given time, the aim is to achieve equilibrium of the three Ps and this should be achieved at the strategic level within an organisation by top level management. According to Bergman, Bergman and Berger (2017), top management respond to Triple 'P's concept with their intellect (head), feelings (heart) and knowledge about behavioural practices (hands) resulting in triple ' $\mathrm{H}$ ' triangle. Bergman et al. further postulate that the integration of the triple ' $\mathrm{P}$ ' triangle and the triple ' $\mathrm{H}$ ' triangle leads to three other triangles that show in visual terms the decision-making process. This new triangle also includes corner segments namely; Operation (What are we going to do?), Organisation (How are we going to do it?) and Origin (Why are we going to do it?).

\section{Application of the 'Triple P' model}

The model can be applied in business decision-making about balancing People, Planet and Profit. It provides an overview of all the dimensions that should be taken into account and states clearly that all dimensions relate to each 
other and should, therefore, be viewed in a mutually coherent way (Slaper \& Hall, 2011). Jonker (2006) posits that the model also helps to assess where a business stands in terms of CSR. By analysing the situation from the perspectives mentioned in the model, a first impression can be provided about the state of affairs of a company. On the basis of this model companies can take action on those issues that are most relevant to them and need to be improved on. While it has been widely argued that engaging in CSR has become a 'must have' for businesses (Bondy et al., 2012), many scholars share the concern that evidence for a business case of CSR continues to be inconclusive at best (Crane et al., 2014; Delmas et al., 2013; Tang et al., 2012). This leaves the cost-benefit-ratio of CSR rather intangible, while there are tangible costs involved in the implementation of CSR in organisational processes.

\subsection{CSR as a Strategic Tool}

Morsing and Schultz (2006) argue that CSR is now being monitored more closely than ever before as consumers have become conscious of responsible business practices. What distinguishes today's understanding of CSR from the past initiatives are present practices of managing CSR strategically and the development of various instruments. Kakabadse, Rozuel and Lee-Davies (2005) reiterate that CSR strategies can create competitive advantages if used properly and that; there is a positive association between strategic social responsibility actions and competitive advantage. CSR has competitive advantage for businesses implying that organisations that carry out corporate social responsibility programmes have certain advantages to benefit from than competitors that do not practice the same. Organisations need to cater for the environment where they carry out their operations in order to earn the goodwill of their stakeholders and this in turn, enhances the performance of the organisation financially and other areas of business (Siltaloppi et al., 2020).

Furthermore, CSR offers organisations various opportunities not only to differentiate themselves from competitors but motivate executives to reconsider their business practices thereby adopting more efficient ways of conducting business. Thus, Robins (2008) avers that the main idea of CSR is for companies to accept the other roles they should play in society more than just being economic oriented. It means an interest to take liability not only for activities and impact in business, but also responsibility for their impact on society and the environment. This commitment as noted by Robins (2008) is thereafter perceived as a significant competitive advantage mostly in highly developed countries.

\subsection{Relationship Between CSR and Business Performance/Survival}

According to the RasGas Magazine (2009), global crisis has proved that corporate social responsibility is not a "nice-to-do" thing but rather a necessity, a concept that businesses must embrace as it positively contributes to business survival by finding equilibrium as proposed by Bergman et al. (2017) Triple 'P' model. The aim of the model is to support the business decision-making processes by integrating People, Planet and Profits. The underlying principle of the triple ' $\mathrm{P}$ ' model is to provide an overview of the driving forces in finding a proper balance and creating value addition for People, the Planet and Profits of a company irrespective of whether a business is making profits or not. Khan et al. (2019) further argue that there is an increasing obligation to integrate CSR in business policies and daily activities and companies have a daunting task when deciding on CSR priorities especially when the bottom line is stressed.

\subsection{CSR Practices in Zimbabwe}

In Zimbabwe, there is no CSR policy; entities are involved on a voluntary basis while some embrace it as a marketing strategy (Dlamini, 2016). There is uncoordinated application of CSR in the absence of consolidated legislation to drive consistency in the reporting, disclosure and financial allocation of CSR activities (Maliki, 2014). In Zimbabwe, CSR is more prevalent in the mining sector and a bit in the manufacturing sector. There is a pronounced drive towards profit maximisation than CSR and social activities (Nyawuyanga, 2015). Matunhu (2012) observes that corporate social responsibility or investment is generally treated as a charitable activity by companies in Zimbabwe. Mathibela (2013) also avers that the socio-economic fabric of Zimbabwean life has been a mixture of uncertainty and lethargy. The author argues that on the business side, corporate governance issues had slackened as companies mainly focused on the proverbial bottom line. Mathibela (2013) further asserts that whilst there are commendable cases of firms that have already led the way for CSR initiatives such as Zimplats, Nestle, Econet, BAT, Tanganda, and Barclays bank to mention but a few, some of which are not on the ZSE, most of the firms in this category have international links and are not necessarily Zimbabwean in origin. This insinuates that they are compelled by virtue of their structure and by their absentee shareholders to take part in these initiatives. However, the challenge still remains that most Zimbabwean owned firms still have a long way to go to reach this level of social service and transcend the spirit of the profit ethic in pursuit of CSR programmes.

Zimbabwean firms cannot afford to take a nap as poverty and disease continue to wreak havoc on the social fabric of communities. Government has proven that social issues are way beyond its mandate and material capability, a development which immediately creates opportunity for the corporate body (Mathibela, 2013). It is unfortunate that, in 
Zimbabwe, there is no comprehensive legislation and policy framework that guides CSR; instead it differs from company to company. There are some fragmented laws and policies that exist such as the Environmental Management Act 13 of 2002, the Indigenisation and Economic Empowerment Act 14 of 2007, the Mines and Minerals Act Chapter 21:5 of 1996 and various other statutory instruments addressing specific areas of the environment.

The Environmental Management Agency was established under the Environmental Management Act [Chapter 20:27] and enacted in 2002. It is responsible for ensuring the sustainable management of natural resources and protection of the environment, the prevention of pollution and environmental degradation. While it does not fully embrace CSR, it however, does cover one of the key arms of the 'Triple Bottom Line' as postulated by Bergman et al. (2017). The Indigenisation and Economic Empowerment Act was enacted to fast track the reform of the mining sector and supporting broad economic empowerment programmes. The objective of the Act was to open up the mining sector to foreign and domestic investment and on the other hand empowering indigenous Zimbabweans in the mining industry to ensure social and economic equity. This culminated in the establishment of the Community Share Ownership Schemes which gave at least, 10 percent shareholding in mines to the local communities. This also mandated foreign and white owned Zimbabwe companies to cede off a minimum 51 percent stake to black Zimbabweans within five years. However, this caused massive capital flight in the mining industry and even crippled FDI in other industries as well. The Zimbabwe Companies Act simply states that companies must engage in CSR activities but does not stipulate how or what they should do to address societal concerns (Nyawuyanga, 2015). The Mines and Minerals Act [Chapter 21:05] section 188(7) and section 189 (1\&2) forces mining companies to behave in a socially responsible way or face the consequences of non-compliance.

\section{Research Methodology}

This study which was conducted in Harare, explored the relevance of CSR to companies during turbulent economic times in Zimbabwe. The following hypothesis was tested:

$\mathrm{H}_{0}$ : There is no relationship between CSR strategies and business survival

$\mathrm{H}_{1}$ : There is a relationship between CSR strategies and business survival

A quantitative survey of 31 purposively selected listed companies that are actively involved in CSR programmes was adopted. The study population included companies on the ZSE listed sectors such as consumer goods, consumer services, industrials, financials, basic materials, telecommunications, oil and gas. The sample of 31 companies was drawn from 59 companies listed on the ZSE. The respondents included corporate affairs and public relations managers, marketing and sales managers, accountants and finance managers. The study focused on listed companies with sound CSR investment programmes. Listed companies are highly regarded as ambassadors of sustainable operations rooted on sound corporate governance and are deemed to be champions of CSR. This has resulted in such companies coming up with comprehensive and internationally recognised CSR strategies. In addition, elements of accountability to shareholders come into play resulting in the listed companies doing that which is right in the eyes of investors or as guided by shareholders. Furthermore, the targeted respondents are, in most cases, the ones who initiate, implement and execute CSR programmes in their companies. This, results in respondents having a greater appreciation and understating of the objectives that their respective companies hope to achieve.

A total of 72 questionnaires were distributed electronically whilst 21 were administered physically. The electronic distribution mode yielded better response compared to the physical one. A maximum of three respondents per identified listed company selected from senior management which included sales/brand managers, public relations/corporate affairs managers, accountants, finance managers, operations/production managers and marketing managers were targeted and the exercise was completed within a space of one and a half months. To ensure reliability, the researcher solicited the participation of corporate affairs and public relations managers, marketing and sales managers, human resources and finance managers (Saunders et al., 2016). The researcher observed the ethical consideration of right to respondent's privacy by not invading into their personal space, used simple language for respondents to clearly understand before obtaining informed consent (Creswell, 2014). Furthermore, respondents were also assured that the information they volunteered was solely for academic purposes.

\section{Reseach Findings and Discussion}

\subsection{Response Rate}

From a purposive sample of 31 companies listed on the Zimbabwe Stock Exchange and practising CSR, 93 respondents were selected to complete the questionnaire. Out of the 93 questionnaires distributed, a total of 74 questionnaires were completed giving a response rate of $80 \%$ which was quite good (Richardson, 2005), $10 \%$ were received after the deadline and the remaining $10 \%$ was not returned. Male respondents were $60.3 \%$ compared to ladies who were $39.7 \%$ while the age range was from 18 to above 55 years. 


\subsection{Line of Business}

Findings revealed a correlation between an organisation's line of business and the exact nature of CSR the company embarked on. Every organisation's situation is unique and this results in each company being defined by what it does. Milton Friedman (1970), believed that an organisation should pursue only its shareholders' economic interests and those who conceive the business organisation as a connection of relations involving a variety of stakeholders without which durable shareholder value creation is impossible. Furthermore, a majority $(66 \%)$ of the surveyed companies had a CSR policy which targets shareholders' interests whilst 34\% did not have a CSR policy though they undertook CSR activities. The study sought to establish the CSR activities which were the most preferred in different organisations. Figure 2 shows the most preferred CSR activities. Since organisations' mandates differ, each organisation listed on the stock exchange pursues CSR programmes that are in line with its mission, vision and values. CSR programmes that are children centred, have the most up-take by listed companies at $48 \%$ followed by health matters at $43 \%$. Environmental issues were at $41 \%$ while sports sponsorship was at $40 \%$. Infrastructure development, support of elderly, youth and gender issues were pegged at $30 \%, 21 \%, 20 \%$ and $8 \%$ respectively as shown in Figure 2 .

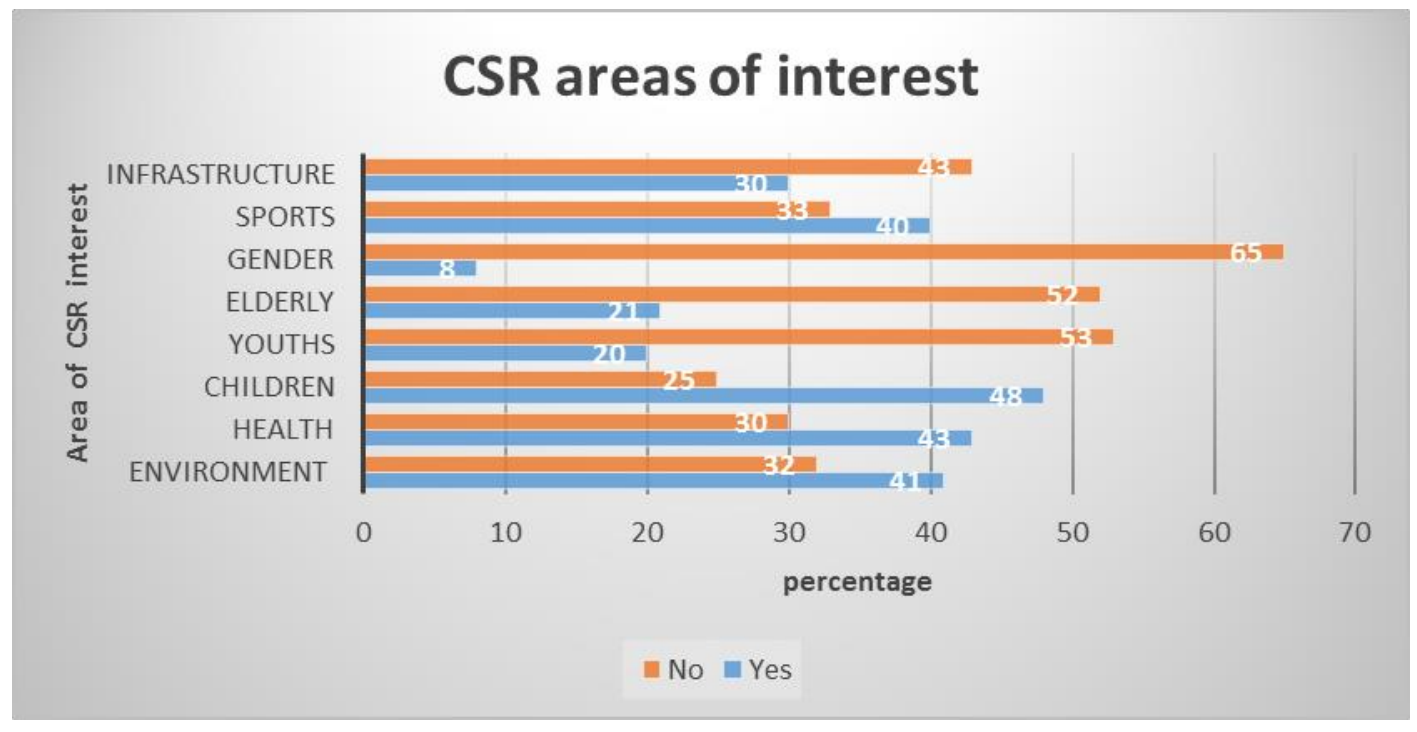

Figure 2. Organisations Area(s) of Interest

The survey further indicated that listed companies align CSR activities with their line of business. For example, CSR programmes on infrastructure and environmental development were mostly from mining and construction industry whilst manufacturers of food and beverages had an interest in health/nutrition and sports sponsorships among children and the youths. As Osterman (2014) postulates, CSR activities are initiatives that are aimed at making CSR central to the company and such activities include alignment of purpose, value, and vision to ensure that CSR is coherent and incorporated in business. It should not conflict with profitability.

\subsubsection{Business Sustainability}

In response to whether CSR had sustained the business in the last three (3) years, $54.8 \%$ were in agreement that CSR had managed to sustain the listed organisations whilst $45.2 \%$ were of the opinion that business survival had nothing to do with CSR. According to Atuluku and Uchendu (2016), CSR is based on the premise that a business can only thrive if it operates within a thriving society. In that way, the business depends on the community it operates within, and as such, has an ethical and moral responsibility towards that community. Business sustainability is based on the premise that business operates in such a way that it uses limited resources to meet its needs today, while still ensuring that resources are still available to meet the needs of future generations.

\subsubsection{CSR Effectiveness}

Figure 3 shows the frequency of measuring the effectiveness of CSR by corporates. Measuring the effectiveness of CSR programmes helps organisations to assess if it is worth investing in corporate social activities in the next financial year. Consequently, $43.8 \%$ of the surveyed companies measured CSR effectiveness annually while $30.10 \%$ measured quarterly, $16.4 \%$ not measuring at all, while $9.6 \%$ measure bi-annually. Overall, CSR was regarded as a facet worth embracing amongst the listed companies sampled as testified by $95 \%$ of the respondents. 


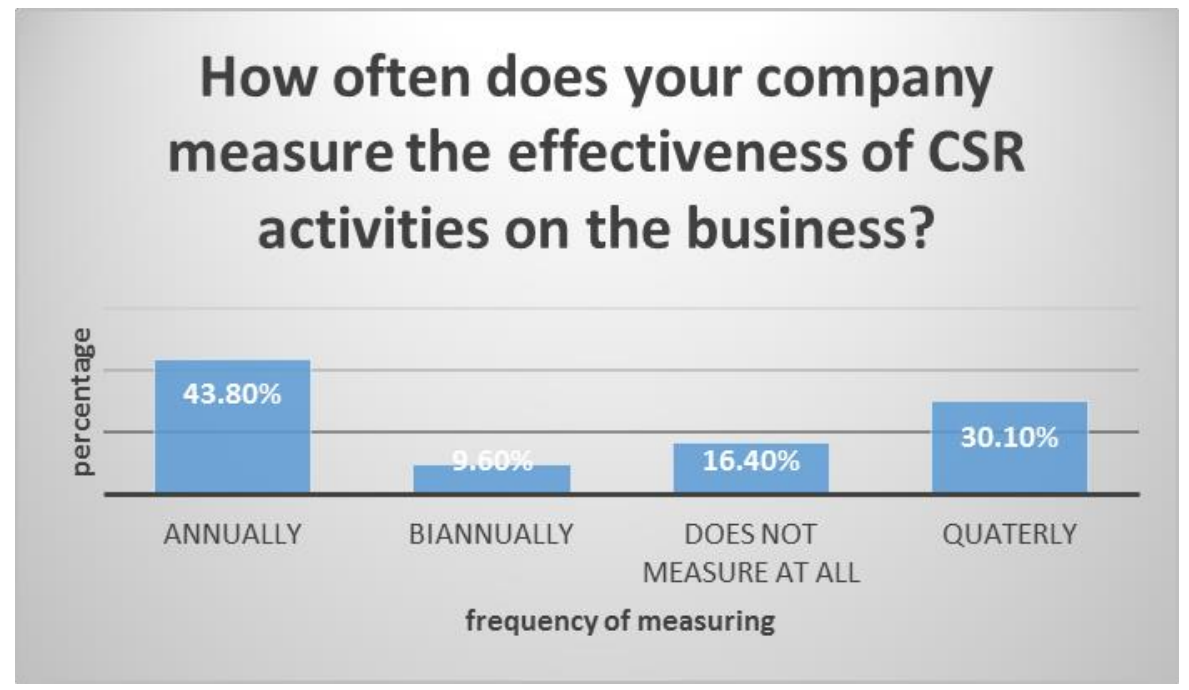

Figure 3. Frequency of measuring CSR effectiveness

\subsection{Communication and Support}

Table 1 highlights the different responses on communication of CSR activities to both internal and external stakeholders. Table 1 also indicates employee involvement and support of the CSR activities undertaken by their companies. Up to 93\% of companies maintained strong communication of their CSR activities to stakeholders. According to Johnson-Cramer et al. (2003), the essence of stakeholder dialogue is the co-creation of shared understanding by company and the stakeholders. Today, participation and dialogue have become a natural element of corporate self-presentations. Messages about corporate ethical and socially responsible initiatives are likely to evoke strong and often positive reactions among stakeholders. Maignan and Ferrel (2013) argue that research has even pointed to the potential business benefits of the internal and external communication of CSR efforts. Brown and Dacin (2011) argue that corporate CSR messages have also proven to attract negative attention. In fact, research suggests that the more companies expose their ethical and social ambitions, the more likely they are to attract critical stakeholder attention (Ashforth \& Gibbs, 1990). Other studies have triggered questions such as 'if a company focuses too intently on communicating CSR associations, is it possible that consumers may believe that the company is trying to hide something?' (Brown \& Dacin, 2011). Furthermore, stakeholder expectations regarding CSR are a moving target and must be considered carefully and more frequently.

Table 1. CSR Activities

\begin{tabular}{|c|c|c|c|c|c|c|}
\hline & & 1 & 2 & 3 & 4 & 5 \\
\hline$i$. & $\begin{array}{l}\text { The organisation communicates its CSR activities to } \\
\text { stakeholders }\end{array}$ & $41.10 \%$ & $52.10 \%$ & $2.70 \%$ & $1.40 \%$ & $2.70 \%$ \\
\hline ii. & $\begin{array}{l}\text { The company gives regular financial support to local } \\
\text { community activities }\end{array}$ & $31.50 \%$ & $39.70 \%$ & $16.40 \%$ & $11.00 \%$ & $1.40 \%$ \\
\hline iii. & Employees are involved in external CSR activities & $12.30 \%$ & $63.00 \%$ & $16.40 \%$ & $6.80 \%$ & $1.40 \%$ \\
\hline$i v$. & $\begin{array}{l}\text { The company gives employees time and financial resources } \\
\text { for CSR activities }\end{array}$ & $13.70 \%$ & $46.60 \%$ & $21.90 \%$ & $15.10 \%$ & $2.70 \%$ \\
\hline v. & The CSR activities have a positive impact in my company & $32.90 \%$ & $46.60 \%$ & $17.80 \%$ & $1.40 \%$ & $1.40 \%$ \\
\hline$v i$. & The company's CSR programmes are worth pursuing & $41.10 \%$ & $30.10 \%$ & $21.90 \%$ & $6.80 \%$ & $0.00 \%$ \\
\hline
\end{tabular}

As shown in Table 1, CSR activities are an important factor on the survival of the organisation. Using a five-point Likert scale ( $1=$ strongly agree up to $5=$ strongly disagree), a cumulative $93 \%$ of respondents indicated that the organisation valued communication of the CSR activities to stakeholders. Furthermore, $71 \%$ respondents attested that the company gives regular financial support to local communities while $73 \%$ indicated that employees are involved in external CSR activities of their organisations. To further augment the importance of CSR, $60 \%$ of the companies gave their employees time and resources for CSR activities, $79.5 \%$ deemed CSR to have a positive impact in their companies. 
Lastly, 71\% companies affirmed that their companies' CSR programmes were indeed worth pursuing.

\subsubsection{CSR Drivers}

Table 2 indicates the various drivers that motivate different companies to engage in CSR.

Table 2. CSR Drivers

\begin{tabular}{|c|c|c|c|c|c|c|}
\hline & & 1 & 2 & 3 & 4 & 5 \\
\hline$i$. & Brand reputation & $37.00 \%$ & $56.20 \%$ & $2.70 \%$ & $1.40 \%$ & $2.70 \%$ \\
\hline ii. & Increased customer loyalty & $37.00 \%$ & $42.50 \%$ & $12.30 \%$ & $4.10 \%$ & $4.10 \%$ \\
\hline iii. & Environmental concern & $30.10 \%$ & $31.50 \%$ & $30.10 \%$ & $5.50 \%$ & $2.70 \%$ \\
\hline$i v$. & Employee engagement and retention & $17.80 \%$ & $23.30 \%$ & $38.40 \%$ & $12.30 \%$ & $8.20 \%$ \\
\hline$v$. & Corporate governance purpose & $46.60 \%$ & $32.90 \%$ & $15.10 \%$ & $2.70 \%$ & $2.70 \%$ \\
\hline$v i$. & Increased sales & $24.70 \%$ & $39.70 \%$ & $28.80 \%$ & $4.10 \%$ & $2.70 \%$ \\
\hline vii. & Regulatory compliance & $31.50 \%$ & $31.50 \%$ & $31.50 \%$ & $4.10 \%$ & $1.40 \%$ \\
\hline viii. & Religion and cultural influence & $6.80 \%$ & $20.50 \%$ & $34.20 \%$ & $28.80 \%$ & $9.60 \%$ \\
\hline$i x$. & Feel good factor & $28.80 \%$ & $35.60 \%$ & $31.50 \%$ & $2.70 \%$ & $1.40 \%$ \\
\hline$x$. & Networking opportunities & $38.40 \%$ & $32.90 \%$ & $15.10 \%$ & $12.30 \%$ & $1.40 \%$ \\
\hline$x i$. & Team Building & $41.10 \%$ & $27.40 \%$ & $23.30 \%$ & $6.80 \%$ & $1.40 \%$ \\
\hline
\end{tabular}

Table 2 shows that $93 \%$ of the respondents confirmed that companies get involved in CSR because they want to enhance the corporate or product brand. As argued by Tencati et al. (2004), CSR now forms part of risk management activities of firms. CSR has become part of a wider strategy for developing competitive advantage via building and protecting corporate and brand reputation. The next CSR driver which motivates companies to get involved in CSR is increased customer loyalty and corporate governance both of which had a rating of 79.5\%. According to Ozyer (2016), brand reputation is the strongest driver of customer loyalty; hence companies seek to increase the equity of their brands. From the survey conducted, corporate governance as a CSR driver was at par with increased customer loyalty. Listed companies are expected to come up with sustainability reports and it is in the reports that issues of corporate governance are reported.

Listed companies disclose their CSR programmes through annual reports or a special sustainability report. From the study, issues of corporate governance are more pronounced amongst banks listed on the Zimbabwe Stock Exchange and this is corroborated by Branco and Rodriques (2008) who argue that banks with higher visibility pay more concern on corporate social disclosure to improve the corporate image than banks with lower visibility. According to Alkin and Yilmaz (2015), measurement of CSR performance is a subjective and judgmental issue. As such, one of the methods to measure performance is scoring based on the organisation's CSR disclosure which is a corporate governance and business survival expectation for listed companies.

\subsubsection{CSR Financing and Performance}

Table 3 demonstrates the importance attached to financing CSR programmes and the value attached to CSR by organisations. On the section relating to the value attached to CSR by companies, it emerged that $89 \%$ of the respondents confirmed that the organisations they work for value CSR to the extent that $85 \%$ confirmed that employers allocate a budget towards CSR as shown in Table 3. Up to 70\% affirmed that CSR budget for their companies is set before profit is declared. According to $81 \%$ of the respondents, customers prefer doing business with companies that are engaged in CSR whilst $75 \%$ were of the opinion that socially responsible companies perform better during turbulent times than their counterparts because society supports such companies by buying products or services even during economic downturn. 
Table 3. CSR Financing and Performance

\begin{tabular}{|c|c|c|c|c|c|c|}
\hline & & 1 & 2 & 3 & 4 & 5 \\
\hline$i$. & My company values CSR in its operations & $50.00 \%$ & $38.90 \%$ & $5.60 \%$ & $4.20 \%$ & $1.40 \%$ \\
\hline ii. & CSR should be mandatory for every company & $23.30 \%$ & $32.90 \%$ & $28.80 \%$ & $15.10 \%$ & $\mathbf{0}$ \\
\hline iii. & My company has an allocated CSR budget & $34.20 \%$ & $50.70 \%$ & $6.80 \%$ & $6.80 \%$ & $1.40 \%$ \\
\hline$i v$. & CSR budget for my company is set before profit is declared & $15.50 \%$ & $54.90 \%$ & $15.50 \%$ & $12.70 \%$ & $1.40 \%$ \\
\hline $\boldsymbol{v}$. & During economic challenges, the CSR budget is not affected & $2.70 \%$ & $21.90 \%$ & $28.80 \%$ & $35.60 \%$ & $11.00 \%$ \\
\hline$v i$. & $\begin{array}{l}\text { During economic turbulent time, the CSR budget is scaled } \\
\text { down }\end{array}$ & $21.90 \%$ & $50.70 \%$ & $11.00 \%$ & $15.10 \%$ & $1.40 \%$ \\
\hline vii. & I am happy with nature of CSR activities in my company & $12.30 \%$ & $61.60 \%$ & $16.40 \%$ & $5.50 \%$ & $4.10 \%$ \\
\hline viii. & Companies that practice CSR perform better & $21.90 \%$ & $53.40 \%$ & $19.20 \%$ & $2.70 \%$ & $2.70 \%$ \\
\hline$i x$. & $\begin{array}{l}\text { Socially responsible companies perform better during } \\
\text { turbulent times than their counter parts }\end{array}$ & $21.90 \%$ & $52.10 \%$ & $17.80 \%$ & $8.20 \%$ & $\mathbf{0}$ \\
\hline$x$. & $\begin{array}{l}\text { When companies are not doing well, investment in CSR can } \\
\text { boost performance }\end{array}$ & $21.90 \%$ & $46.60 \%$ & $21.90 \%$ & $8.20 \%$ & $1.40 \%$ \\
\hline$x i$. & $\begin{array}{l}\text { Companies should engage in CSR only when they make } \\
\text { profits }\end{array}$ & $12.30 \%$ & $2.70 \%$ & $19.20 \%$ & $46.60 \%$ & $19.20 \%$ \\
\hline xii. & $\begin{array}{l}\text { Customers prefer doing business with companies that } \\
\text { engage in CSR }\end{array}$ & $28.80 \%$ & $52.10 \%$ & $12.30 \%$ & & \\
\hline
\end{tabular}

Table 4 summarises the means by which CSR is incorporated into the whole organisational strategy. Aligning company value to the cause is one most preferred way by listed companies to incorporate CSR into the overall organisational strategy as confirmed by $73 \%$ of the respondents. Most manufacturing companies listed on the ZSE were of the opinion that CSR should be aligned with business strategy of corporates. One leading mining company in Zimbabwe stated that CSR has of late, evolved to creating shared values (CSV). To achieve CSV, listed mining companies that participated in the survey revealed that they align business by collaborating with local communities through chiefs who at times request that traditional rites be observed before a certain area in the community is mined.

Table 4. Incorporating CSR into the organizational strategy

\begin{tabular}{|c|c|c|c|c|c|c|}
\hline & & 1 & 2 & 3 & 4 & 5 \\
\hline$i$. & Aligning company value to the cause & $38.40 \%$ & $34.20 \%$ & $23.30 \%$ & $2.70 \%$ & $1.40 \%$ \\
\hline ii. & Identifying matters with immediate impact & $24.70 \%$ & $46.60 \%$ & $17.80 \%$ & $9.60 \%$ & $1.40 \%$ \\
\hline iii. & Fixing what the business does wrong & $23.30 \%$ & $37.00 \%$ & $26.00 \%$ & $11.00 \%$ & $2.70 \%$ \\
\hline$i v$. & Value creation through the company's value chain & $21.90 \%$ & $35.60 \%$ & $26.00 \%$ & $12.30 \%$ & $4.10 \%$ \\
\hline$v$. & Building distinct corporate culture among employees & $11.00 \%$ & $49.30 \%$ & $19.20 \%$ & $15.10 \%$ & $5.50 \%$ \\
\hline$v i$. & Partnering with a third party & $8.20 \%$ & $52.10 \%$ & $20.50 \%$ & $17.80 \%$ & $1.40 \%$ \\
\hline
\end{tabular}

Collaboration is also done with agencies like Environmental Management Authority (EMA), whilst those in the dairy sector collaborate with dairy farmers, schools and colleges across the country to create awareness on health and nutrition among the youths through sports. One dairy company embarked on projects to encourage rural based women to be financially independent through good dairy practices and milk from imported heifers by the same company already contributes $21 \%$ of national milk intake from farmers.

\section{Hypothesis testing}

$\mathrm{H}_{0}$ : There is no relationship between CSR strategies and business survival

$\mathrm{H}_{1}$ : There is a relationship between CSR strategies and business survival 


\subsubsection{Chi-Square Test}

A Chi-square was conducted to test and establish the relationship between CSR strategies and business survival on companies listed on the Zimbabwe Stock Exchange. The results are shown in Table 5.

Rejection criteria: Reject $\mathrm{H}_{0}$ if Pcal $<$ than $\mathrm{P}$ (alpha 0.05 ) at $95 \%$ confidence intervals

Table 5. Pearson Chi-Square

\begin{tabular}{llll}
\hline & Value & df & P-Value \\
\hline Pearson Chi-Square & $\mathbf{6 . 2 4 5}$ & $\mathbf{1}$ & $\mathbf{0 . 0 0 2}$ \\
Continuity Correction & 8.511 & 1 & \\
Likelihood Ratio & 10.723 & 1 & 0.002 \\
Fisher's Exact Test & & & 0.002 \\
No of Valid Cases & 74 & & \\
\hline
\end{tabular}

\section{Test deduction/Findings}

The Chi-square test conducted revealed that there is a relationship between CSR strategies and business survival since $\mathrm{P}$ (cal) is 0.02 and it is less than $\mathrm{P}$ (alpha) 0.05 . We therefore, reject $\mathrm{H}_{0}$ and accept $\mathrm{H}_{1}$. There were significant differences between listed companies that incorporated CSR activities as part of their corporate strategy and those that did not. Companies with CSR strategies had a higher chance of surviving during turbulent times with P-values (0.02) at $95 \%$ Confidence Interval (CI).

\subsubsection{Validation Test}

Table 6 shows further validation tests on relationship between CSR and business survival

Table 6. CSR vs Business Survival

\begin{tabular}{lllllll}
\hline & & Value & Approx. Sig. & Monte Carlo Sig. \\
\hline & & & & P-Value & $95 \%$ Confidence Interval \\
\multirow{2}{*}{ Nominal by Nominal } & Phi & & & & Lower Bound & Upper Bound \\
& Cramer's V & .372 & .001 & $.002^{\mathrm{a}}$ & .001 & .003 \\
No of Valid Cases & & .372 & .001 & $.002^{\mathrm{a}}$ & .001 & .003 \\
& & 74 & & & &
\end{tabular}

The chi square test was further validated using the V-Cramer's test and the Phi test which also showed a strong relationship with Phi test P (0.01) and CI 0.01-0.03) at 95\% CI between organisations having CSR activities as part of their corporate strategy and business survival.

\section{Conclusion and Recommendations}

\subsection{Conclusion}

The conclusions of the study are as follows:

\subsubsection{Relevance of CSR}

Regardless of the economic situation within the country, CSR practice is relevant as it is beneficial to the company while at the same time stakeholders become loyal irrespective of the economic situation. Listed companies are appreciated when they invest in CSR during an economic downturn as this result in better community relations and improved business image. Asemah et al. (2013) aver that proponents of CSR as a social obligation posit that a company engages in socially responsible behaviour when it thinks of profits only within the constraints of law. They believe that because the society supports business by ensuring its continuous existence, the only way business can repay society is to continue to ensure that it is making profits irrespective of the economic conditions. Businesses that practice CSR have a better reputation, implying that there is a positive image of the company in the public eyes and that converts into customer loyalty and subsequent increase in sales. As per hypothesis $\mathrm{H}_{1}$ : There is a relationship between CSR strategies and business survival.

\subsubsection{CSR as an Important Strategic Tool}

The study further concluded that companies listed on the Zimbabwe Stock Exchange perceive CSR activities critical as they meaningfully contribute to the overall strategy of the organisation. CSR is of strategic importance to listed 
companies as testified by $79.5 \%$ of the respondents. This is because listed companies have ethical expectations that define acceptable behaviour. As listed companies, the element of good corporate citizen is expected of them in the eyes of stakeholders and they are obliged to present themselves as such. On the other hand, listed companies are expected to observe corporate governance issues relating to disclosure which promotes transparency of the organisation through sustainable reports. Voluntary reporting standards such as the Global Reporting Initiative and King 111, which have become widely accepted have also played a critical role in up scaling CSR to the level of importance in relation to strategy.

\subsubsection{CSR Drivers}

The findings also show that CSR programmes are driven by the nature of business that a listed company pursues with the majority sliding into the role previously occupied by government in taking responsibility of improving living standards of stakeholders. The leading driver was that of brand reputation with $93 \%$ of the respondents attesting to corporate image as the key motivator to consider CSR as an important area to invest in. As confirmed by extant literature, CSR of late is driven by the need to stay ahead of rapidly changing economies and most socially responsible listed organisations continue to revise their short and long-term agendas in line with an organisation's mandate.

\subsubsection{Monitoring and Evaluation of CSR}

On monitoring and evaluation of CSR programmes, the findings revealed that $59 \%$ of the listed companies monitor and evaluate their CSR investments programmes. The rest of the companies studied just implement CSR without measuring and evaluating its impact on the business. Monitoring and evaluation of the CSR programmes helps organisations in learning from past experiences, improving delivery system of CSR activities undertaken, systematic planning and optimising resource allocation and measurement of results as part of accountability to key stakeholders. It aids in enhancing the ability to consult, coordinate and engage with various stakeholders resulting in identifying relevant issues in a time-bound manner which in turn enhances the ability to address the CSR issues through proper performance indicators of CSR activities (CSR and Sustainability Institute, New York).

\subsection{Recommendations}

\subsubsection{Policy Formulation}

Based on the findings of the study, it is recommended that government comes up with CSR industry policies that compel organisations to operate responsibly. There is need for the government to push for CSR practices that address the damage they cause to society. Once policies are in place, government can partner corporates through CSR to achieve national development goals. Through the adoption of a CSR policy framework, government can compel companies such as mining and construction to engage in CSR activities that contribute towards the rebuilding and improvement of infrastructure and the environment of the communities they operate in. Various studies have shown that the world over, governments are lacking on the welfare state of citizens by failing to provide social services, hence the need for governments to partner with the private sector in order to provide such services. Most governments are concerned with embracing UN Millennium Development Goals such as eradication of extreme poverty and hunger, promoting gender equality and empowering women, achieving universal primary education, ensuring environmental sustainability and combating HIV/AIDS among others. On such issues, governments cannot walk alone but must partner industry through corporate social investment if tangible results are to be realised.

\subsubsection{Continued Investment in CSR}

Furthermore, it is recommended that organisations continue to invest in CSR irrespective of the economic situation. Companies that practice CSR have a higher chance of survival during turbulent times. If the CSR budget is scaled down, corporates can focus on CSR matters that yield zero cost on their part in an effort to occupy top of the mind awareness among stakeholders at all time. Austin et al. (2006) argue that consumers are known to "punish" companies they believe are behaving socially irresponsible through product boycotts and encouraging others to do the same. Osterman (2014) corroborates this view by arguing that consumers encompass the power to punish companies that are not acting in a way that they consider responsible when the need arises. Consumers remember organisations that help them in times of need leading to them being loyal customers. As such CSR must always be on the radar for listed companies.

\section{References}

Alkin, A., \& Yilmaz, I. (2015). Drivers of Corporate Social Responsibility Disclosures: Evidence from Turkish Banking Sector. Fatih University: Istanbul, 34500, Turkey

Asemah, E. S., Okpanachi, R. A., \& Olumuji, E. O. (2013). Communicating corporate social responsibility performance of organisations: A key to winning stakeholders' goodwill. International Journal of Arts and Humanities, 2(3), 34-41. 
Ashforth, B. E., \& Gibbs, B. W. (1990). The double edge of organisational legitimation. Organization Science, 1, $177-194$. https://doi.org/10.1287/orsc.1.2.177

Atuluku, A., \& Uchendu, J. (2016). Between Corporate Social Responsibility and Business Sustainability. Part 5/13 of the Business Sustainability in Nigeria Series. Abuja University Press.

Austin, J., Gutierrez, R., Ogliastri, E., \& Reffricco, E. (2006). Effective management of social enterprises. Lessons from Business and Civil Society Organizations in Iberoamerica, Harvard University Press.

Baker, H. K., \& Anderson, R. (2010). Corporate Governance: A synthesis of theory, research and practice. John Wiley and Sons Inc. New Jersey. https://doi.org/10.1002/9781118258439

Bergman, M. M., Bergman, Z., \& Berger, L. (2017). An empirical exploration, typology and definition of corporate sustainability. Sustainability MDPI, 9. https://doi.org/10.3390/su9050753

Bondy, K., Moon, J., \& Matten, D. (2012). An institution of corporate social responsibility (CSR) in multinational corporations (MNCs): form and implications. Journal of Business Ethics, 111(2), 281-299. https://doi.org/10.1007/s10551-012-1208-7

Branco, M. C., \& Rodrigues, L. L. (2008). Factors influencing social responsibility disclosure by Portuguese companies. Journal of Business Ethics, 83, 691 https://doi.org/10.1007/s10551-007-9658-Z

Brown, T. J., \& Dacin, P. A. (2011). The company and the product: corporate associations and consumer product responses. Journal of Marketing, 61(1), 68-84. https://doi.org/10.1177/002224299706100106

Clarke, V., \& Braun, V. (2013). Successful qualitative research: a practical guide for beginners. Retrieved from http://eprints.uwe.ac.uk/21156

Confederation of Zimbabwe Industries. (2011). State of the Manufacturing Sector Survey. Harare: Confederation of Zimbabwe Industries.

Crane, A., Matten, D., \& Spence, L. J. (2014). Corporate social responsibility: readings and cases in a global context. London: Routledge.

Creswell, J. W. (2014). Research Design: Qualitative, quantitative, and mixed methods approaches (3rd ed.). Thousand Oaks, CA: Sage.

Defoe, D. (2020). Arguments for and against corporate social responsibility.

Delmas, M. A., Etzion, D., \& Nairn-Birch, N. (2013). Triangulating environmental performance: what do corporate social responsibility ratings really capture? Academy of Management Executive, 27(3), $255-267$. https://doi.org/10.5465/amp.2012.0123

Dlamini, B. (2016). The impact of CSR on company profitability in Zimbabwe: a case of a listed company. International Journal of Social Science and Economic Intervention, 2(4), 9-16 https://doi.org/10.23958/ijssei/vol02-i04/02

Friedman, M. (1970). The Social Responsibility of Business is to Increase its Profits. The New York Times Magazine, New York, 14 September 1970

Hopkins, M., Roche, J., \& Hopkins, I. (2008). CSR in turbulent times: Now needed more than ever before. Retrieved from http://mhcinternational.com://monthly-features/articles

Johnson-Cramer, M. E., Berman, S. L., \& Post, J. E. (2003). Re-examining the concept of stakeholder management. Unfolding Stakeholder Thinking. Greenleaf UK. https://doi.org/10.9774/GLEAF.978-1-909493-32-2_10

Jeou, S. H., Hsuan, H., \& Chang-Yen, T. (2018). An assessment model of corporate social responsibility practice in the tourism industry. Journal of Sustainable Tourism, 26(7), 1085-1104, https://doi.org/10.1080/09669582.2017.1388384

Jonker, J. (2006). Management Models for Corporate Social Responsibility. New York: Springer. https://doi.org/10.1007/3-540-33247-2

Kakabadse, N. K., Rozuel, C., \& Lee-Davies, L. (2005). Corporate social responsibility and stakeholder approach: A conceptual review. International Journal of Business. https://doi.org/10.1504/IJBGE.2005.006733

Khan, S. A. R., Yu, Z., Golpira, H., \& Sharif, A. (2019). The nexus between corporate social responsibility and corporate performance: an empirical evidence. Logforum, 15(2), 291-303. https://doi.org/10.17270/J.LOG.2019.328

Maignan, I., \& Ferrell, O. C. (2013). Nature of corporate responsibilities: perspectives from American, French, and German consumers. Journal of Business Research, 45(4), 56-65. 
Maliki, H. (2014). Corporate social responsibility in Zimbabwe: Emerging Trends in the financial services sector. Unpublished EMBA Dissertation. MSUIR Repository.

Mathibela, A. (2013). Corporate Social Responsibility in Zimbabwean business. Retrieved from Povo.co.zw/features/corporate-social-responsibility-zimbabwean-business

Matunhu, J. D. (2012). Poverty and corporate social responsibility in Africa: a critical assessment. International Journal of Open \& Distance Learning. International Research Conference Edition.

Morsing, M., \& Schultz, M. (2006). Corporate social responsibility communication: stakeholder information, response and involvement strategies. Business Ethics: A European Review, 15(4), 323-338. https://doi.org/10.1111/j.1467-8608.2006.00460.x

Nyawuyanga, T. M. (2015). Corporate social responsibility as a tool to accelerate the achievement of Development Goals in Zimbabwe. Thesis submitted in partial fulfilment of the requirements for the award of LL.M Degree in the Faculty of Law, University of Western Cape.

Onyebuche, O., \& Nwaeke, L. I. (2019). Impact of corporate social responsibility practices and disclosures on organizational survival. International Journal of Social Sciences and Management Research, 5(2). Retrieved from www.iiardpub.org

Osterman, C. (2014). Why companies engage in CSR. Lund University School of Economics and Management. Sweden: Lund University.

Ozyer, Y. (2016). Understanding the impact of the brand experience on brand reputation by the moderating role of technology turbulence. International Journal of Marketing Studies, 8(1), 161-169. https://doi.org/10.5539/ijms.v8n1p161

RasGas Magazine. (2009). A longer term view. Retrieved from http://www.rasgas.com/files

Richardson, J. T. E. (2005). Instruments for obtaining student feedback: a review of the literature. Assessment \& Evaluation in Higher Education, 30(4), 387-415. https://doi.org/10.1080/02602930500099193

Robins, F. (2008). Why corporate social responsibility should be popularised but not imposed. Corporate Governance Journal, 8(3), 330-341. https://doi.org/10.1108/14720700810879204

Saunders, M. L., Thornhill, P., \& Lewis, P. (2016). Research methods for business students. 7th Edition. London: Pearson Education.

Schraa-Liu, T., \& Trompenaars, F. (2006). Towards Responsible Leadership Through Reconciling Dilemmas. London: Routledge.

Siltaloppi, J., Rajala, R., \& Hietala, H. (2020). Integrating CSR with Business Strategy: A Tension Management Perspective. Journal of Business Ethics. https://doi.org/10.1007/s10551-020-04569-3

Slaper, T. F., \& Hall, T. J. (2011). The Triple Bottom Line: What Is It and How Does It Work? Indiana Business Review.

Tang, Z., Hull, C. E., \& Rothenberg, S. (2012). How corporate social responsibility engagement strategy moderates the CSR-financial performance relationship. Journal of Management Studies, 49(7), 1274-1303. https://doi.org/10.1111/j.1467-6486.2012.01068.x

Tencati, A., Perrini, F., \& Pogutz, S. (2004). New tools to foster corporate socially responsible behaviour. Journal of Business Ethics, 53, 173. https://doi.org/10.1023/B:BUSI.0000039407.37497.44

Zurita, P. C. (2006). We are socially responsible: Framing analysis of corporate PR and their CSR messages. Athens: University of Georgia.

\section{Copyrights}

Copyright for this article is retained by the author(s), with first publication rights granted to the journal.

This is an open-access article distributed under the terms and conditions of the Creative Commons Attribution license which permits unrestricted use, distribution, and reproduction in any medium, provided the original work is properly cited. 